\title{
Seasonal Variation in Populations of 'Candidatus Liberibacter asiaticus' in Citrus Trees in Paraná State, Brazil
}

\author{
Aline Vanessa Sauer, Carlos Alexandre Zanutto, and Paula Thais Requena Nocchi, Núcleo de Pesquisa em Biotecnologia Aplicada \\ (NBA), Universidade Estadual de Maringá (UEM) 87020-900, Maringá, Paraná, Brazil; Marcos Antonio Machado, Centro de Citricultura \\ "Sylvio Moreira", Instituto Agronomico de Campinas, 13490-970, Cordeirópolis, SP, Brazil; Clive H. Bock, United States Department of \\ Agriculture-Agricultural Research Service SEFTNRL, Byron, GA 31008; and William M. C. Nunes, NBA UEM, Brazil
}

\begin{abstract}
Sauer, A. V., Zanutto, C. A., Nocchi, P. T. R., Machado, M. A., Bock, C. H., and Nunes, W. M. C. 2015. Seasonal variation in populations of 'Candidatus Liberibacter asiaticus' in citrus trees in Paraná state, Brazil. Plant Dis. 99:1125-1132.

Huanglongbing (HLB) is considered one of the most destructive diseases of citrus because the plants rapidly become unproductive, enter a decline, and eventually die. HLB is caused by the phloem-limited bacterium 'Candidatus Liberibacter' spp. The objective of this study was to evaluate seasonal variation of the in planta population of ' $\mathrm{Ca}$. Liberibacter asiaticus' in the foliage of citrus trees in Brazil using real-time polymerase chain reaction (qPCR). Eleven plants (naturally infected, then screened) in the field with very mild and localized symptoms of HLB were confirmed to be ' $\mathrm{Ca}$. L . asiaticus' infected by conventional $\mathrm{PCR}$, and the canopies were divided into four quadrants. The bacterial population in the trees was tested on a monthly basis for up to 20 months by quantifying ' $\mathrm{Ca}$. L. asiaticus' DNA using qPCR ' $\mathrm{Ca}$. L. asiaticus'specific primers (As84F/As180R). The average cycle threshold $\left(\mathrm{C}_{t}\right)$ values, which relate to ' $\mathrm{Ca}$. L. asiaticus' titer, were analyzed using a mixed

model. Significant differences were observed in $\mathrm{C}_{\mathrm{t}}$ values between seasons $(F=8.77, P=0.0004)$, and abrupt changes were observed in $C_{t}$ values in different quadrants of the trees. Autumn had the lowest $C_{t}$ values, indicating the highest ' $\mathrm{Ca}$. L. asiaticus' titer, and, thus, is considered the best period to detect ' $\mathrm{Ca}$. L. asiaticus' infection in foliage of citrus trees in southern Brazil. In addition to the seasonal changes in $\mathrm{C}_{\mathrm{t}}$ values, there was an initial decline in the $\mathrm{C}_{\mathrm{t}}$ value in the months following initial detection, the rate of decline slowing with time. Concomitant with the increase of the bacterial population in the host, there was an increase in severity of HLB symptoms in the trees over time (Spearman's rank correlation, $r=-0.4083, P<0.0001$ ). The results identify the optimal season to sample foliage for ' $\mathrm{Ca}$. L. asiaticus' in southern Brazil (autumn) and confirm the importance of sample timing to maximize detection of ' $\mathrm{Ca}$. L $\mathrm{L}$. asiaticus' and, thus, contribute to the search for effective measures to manage HLB.
\end{abstract}

Citrus is an important crop in many tropical and subtropical regions of the world; in Brazil, the crop is a major component of the national economy, both in value and for employment within the industry, and indirectly in ancillary industries. Indeed, Brazil is the largest producer of citrus in the world (13), with an estimated production of 20 million tons $(13,20)$ produced from an area estimated at 740,000 ha (20). However, Brazilian citriculture suffers substantial losses due to citrus pests and diseases that have been introduced (18). Among the citrus diseases that impact production, huanglongbing (HLB) is the most important disease of citrus worldwide and is devastating in Brazil $(14,15)$. HLB causes fruit drop, rapid tree decline, and, eventually, tree death (11), and is caused by three different phloemrestricted, gram-negative bacteria (22): 'Candidatus Liberibacter africanus', 'Ca. L. americanus', and ' $C a$. L. asiaticus'. ' $C a$. L. asiaticus' occurs in Asia, the Arabian Peninsula, Brazil, and the United States (11). In Brazil, over 95\% of HLB cases are caused by ' $C a$. L. asiaticus' but ' $\mathrm{Ca}$. L. americanus' is also present $(6,39)$. The disease was first detected in Paraná State in 2007 (35). Two species of psyllids transmit the HLB bacterium: Diaphorina citri is the vector of ' $\mathrm{Ca}$. L. asiaticus' and ' $\mathrm{Ca}$. L. americanus' and Trioza erytreae is the vector of ' $C a$. L. africanus'. These vectors are responsible for spread of HLB in Asia and America, and Africa, respectively (7,11). Recently, D. communis in Bhutan was found to carry ' $\mathrm{Ca}$. L. asiaticus' (12) and, in China, the psyllid Cacopsylla citrisuga has been identified as a new vector (6).

Initial symptoms of HLB are evident on branches or twigs that develop a yellowing of the leaves which eventually spreads through the entire canopy of the tree as the disease develops. The leaves have

Corresponding author: W. M. C. Nunes; E-mail: william.nunes@pq.cnpq.br Accepted for publication 17 January 2015.

http://dx.doi.org/10.1094/PDIS-09-14-0926-RE

(C) 2015 The American Phytopathological Society a mottled appearance, with colors consisting of many shades of light green, dark green, and yellow $(4,7,14)$. Symptomatic fruit are small, defective, and asymmetric, with irregular external coloring, and may show inversion of maturation and uneven ripening. Internally, there may be aborted seed, columella displacement, and internal brown to light-brown vascular bundles (4). However, the symptoms can be somewhat variable and can mimic other physiological conditions and, thus, are not always straightforward to detect. Root colonization is early and widespread, resulting in root death, and acts as a source of inoculum for the canopy as starch reserves are mobilized (23).

Furthermore, there can be a variable period between infection and development of symptoms of HLB $(15,16,23,43)$, also making early detection problematic based on symptoms alone. The development of molecular diagnostics has facilitated detection greatly $(15,32,39,41)$. The practical issues of sampling roots (23), where early, more consistent populations of ' $\mathrm{Ca}$. L. asiaticus' occur, combined with the often low bacterial titers of the HLB-causing organisms in the host canopies can still hinder the detection of the pathogen, especially in asymptomatic trees that are carriers of latent infection $(19,41)$. The prevalence of ' $\mathrm{Ca}$. L. asiaticus' in Brazil is due, at least in part, to the greater probability of spread of this species by the insect vector $D$. citri; ' $C a$. L. americanus' typically has lower bacterial titers compared with those of ' $C a$. L. asiaticus' $(9,30,32)$.

Pathogen quantification is considered an important tool in the research of the disease epidemiology (30), particularly to help understand the movement of the pathogen and its proliferation and distribution both at the field scale and in plant tissues $(17,23,24,38)$. Techniques for detection of the pathogens have been improved in order to obtain more accurate diagnoses and quantification (thereby aiding our understanding of the mechanisms of virulence of these pathogens), assess transmission, monitor epidemic development, and help develop effective management strategies for HLB $(1,2,5,17)$.

To avoid lengthy and laborious diagnoses, researchers have developed various molecular techniques with different specific primers for the detection and quantification of the etiologic agent of HLB 
$(25,26,29,32,39-41,43)$. Real-time (or quantitative) polymerase chain reaction (qPCR) has been shown to be more sensitive and efficient for the detection of ' $\mathrm{Ca}$. Liberibacter' spp. when compared with conventional PCR $(26,32,41)$. The TaqMan probe based on the $16 \mathrm{~S}$ ribosomal DNA sequence that was developed for the qPCR process allows the determination of bacterial concentration in different plant tissues, including the leaf petiole and tissues and membranes of fruit, roots, and leaves (27). The qPCR method has superior sensitivity compared with the other probes and is pathogen specific and, thus, is a very useful research tool for diagnosing and quantifying ' $\mathrm{Ca}$. Liberibacter' spp. $(25,26)$.

The qPCR method has been used to quantify ' $\mathrm{Ca}$. Liberibacter' spp. in citrus $(27,38)$. Results indicated that the pathogen is ubiquitous in symptomatic citrus trees but there is great variation both between individual trees and within different tissues from the same tree. Recently, temperature has been shown to impact populations of ' $\mathrm{Ca}$. L. asiaticus' in both the vector and the host $(30,37)$ and, in many parts of the world where citrus is grown, there is a large seasonal fluctuation in temperature. Irey et al. (21) reported that, in Florida, the most symptomatic samples were received in their diagnostic lab from August to January (midsummer, autumn, and early winter) and these had greatest percentage of HLB positives using qPCR. However, during the less optimum times of year (February to June: winter to early summer), only the blotchy mottle symptoms were prevalent and also tested positive for HLB, although with a lower incidence of positives overall. In another study, also in Florida, the seasonal variation in populations of ' $\mathrm{Ca}$. L. asiaticus' were characterized and the highest ' $\mathrm{Ca}$. L. asiaticus' bacterial titers were observed in December (autumn-early winter), and the lowest ' $\mathrm{Ca}$. L. asiaticus' bacterial titers were recorded in April (spring-early summer), with the variation generally coinciding with HLB symptoms in the field (42); thus, having general agreement with the Irey et al. (21) observations. Similarly, but based on incidence of detection in trees, in Pakistan it was found that, during spring, only $18 \%$ of tree samples were ' $C a$. L. asiaticus' positive but, in summer, $32 \%$ of tree samples were positive (37). Recent work in Florida has provided compelling evidence that the population of ' $\mathrm{Ca}$. L. asiaticus' is not only greater in the roots (23) but also more consistent, perhaps making the roots a more reliable sample source to test for HLB.

The dynamics of in plant populations of ' $\mathrm{Ca}$. L. asiaticus' in fieldgrown citrus in Brazil have not been characterized but it is important to confirm whether similar dynamics exist in the foliage as reported elsewhere. The psyllid relies on ' $\mathrm{Ca}$. L. asiaticus' populations present in foliage to acquire and transmit the pathogen. Characterizing the ' $C a$. L. asiaticus' population in the canopy provides valuable information for understanding aspects of ' $\mathrm{Ca}$. L. asiaticus' populations and transmission of the bacterium; knowledge of ' $\mathrm{Ca}$. L. asiaticus' populations in foliage provides a basis for appropriate sampling to be used in developing novel disease control strategies to eventually help manage HLB.

The aim of this research was to characterize seasonal variation of ' $C a$. L. asiaticus' in the foliage of HLB-affected citrus trees in Brazil. Specifically, the populations of the bacterium were monitored using qPCR in naturally HLB-infected trees in orchards of both sweet orange (Citrus sinensis Osbeck) and Tahiti lime (C. aurantifolia Swingle) in Paraná State, in southern Brazil.

\section{Material and Methods}

Surveys, diagnosis of HLB, and tree selection. Visual assessments of trees in citrus orchards were performed to identify trees with the earliest symptoms of HLB that would be suitable for the experiment. The surveys were done in an experimental orchard of sweet orange trees (planted in 2004) at the Iguatemi Experimental Farm (IEF), State University of Maringá, Maringá, Paraná State $\left(23^{\circ} 21^{\prime}\right.$ $23^{\prime \prime} \mathrm{S}, 51^{\circ} 04^{\prime} 18^{\prime \prime} \mathrm{W}, 550 \mathrm{~m}$ in altitude) in September 2010; in a commercial orchard (Chuva de Prata) of Tahiti lime trees (planted in 2009), also in Maringá in Paraná State $\left(23^{\circ} 25^{\prime} 50^{\prime \prime} \mathrm{S}, 51^{\circ} 59^{\prime} 39^{\prime \prime}\right.$ W, $596 \mathrm{~m}$ in altitude) in September 2010; and in a commercial orchard (Estrela Farm) of sweet orange trees (planted in 2004) in Paranavaí (also in Paraná State) $\left(23^{\circ} 01^{\prime} 44^{\prime \prime} \mathrm{S}, 52^{\circ} 40^{\prime} 16^{\prime \prime} \mathrm{W}, 470 \mathrm{~m}\right.$ in altitude) in June 2008. Weather data for Maringa were obtained from the IEF meteorological station, located at the experimental farm in Maringa. There weather data were used for both locations in Maringa: for the sweet orange orchard at the IEF (where the weather station is located) and for the Tahiti lime orchard at the Chuva de Prata farm (16 km from the IEF meteorological station). The weather data for Paranavai (the sweet orange orchard at the Estrela farm, $83 \mathrm{~km}$ from IEF) were obtained from the weather station at the Agronomic Institute of Paraná weather station (Paulo Antonio da Costa Street, s/n CEP 87701-970, Jardim Ipê, Paranavai, Parana State, Brazil).

Trees with early symptoms of HLB were identified and selected, and 10 symptomatic leaves were collected arbitrarily as a composite sample from each tree. The samples were taken to the laboratory (at the Center for Research in Applied Biotechnology, Núcleo de Pesquisa em Biotecnologia Aplicada, Universidade Estadual de Maringá), where the leaf lamina from each of the 10 leaves in the sample was discarded and the midribs were macerated using a pestle and mortar with the aid of liquid nitrogen to obtain a fine powder. Total DNA was extracted using the cetyltrimethylammonium bromide (CTAB) method (34). The diagnosis of ' $\mathrm{Ca}$. L. asiaticus' was made using conventional PCR with the synthetic primers LPAS (5'TGGTGATAGGGTGGATTTAG-3')/ RPAS (5'TGGTGATAGGGTGGATTTAG-3') following the protocol and amplification conditions described by Coletta-Filho et al. (10), with minor modifications. The PCR amplification was carried out in $25 \mu \mathrm{l}$ containing $2.5 \mu \mathrm{l}$ of $10 \times$ buffer, $2.5 \mathrm{mM} \mathrm{MgCl}_{2}, 2.5 \mathrm{mM}$ dNTP, $2.0 \mathrm{U}$ of Taq DNA polymerase, $5 \mu \mathrm{l}$ of total DNA extract, and $25 \mathrm{ng}$ of each primer. A thermal cycler (MasterCycler Gradient; Eppendorf, Hamburg, Germany) programmed with the following PCR sequence was used: a denaturation step at $94^{\circ} \mathrm{C}$ for $3 \mathrm{~min} ; 35$ cycles of amplification consisting of $94^{\circ} \mathrm{C}$ for $30 \mathrm{~s}, 60^{\circ} \mathrm{C}$ for $45 \mathrm{~s}$, and $72^{\circ} \mathrm{C}$ for $45 \mathrm{~s}$; and ending with a final extension step at $72^{\circ} \mathrm{C}$ for 10 min. HLB-infected and healthy citrus trees ('Pera' on 'Limão Cravo' rootstock) were maintained under greenhouse conditions and were used as a positive control and negative control, respectively. For the positive control, the healthy trees were inoculated in 2008 with buds from confirmed HLB-infected trees from Araraquara, São Paulo State, Brazil. The purification and quantification of DNA was performed as previously described, and the confirmation of positive diagnosis as described by Coletta-Filho et al. (8). Successful amplification was confirmed by $1 \%$ agarose electrophoresis with ethidium bromide. Positive amplifications for ' $\mathrm{Ca}$. L. asiaticus' showed an amplicon of $960 \mathrm{bp}$.

Establishment of the experiment in the field. After confirming infection of the selected trees by conventional PCR, the experiment was established in the field in each of the three orchards. Prior to further sampling, the diseased trees were protected with an antiaphid screen to prevent psyllid transmission of the pathogen within the orchard and also to prevent the possibility of any new infections of the test trees.

At the Estrela farm, the selected HLB-diseased trees of sweet orange were protected against reinfection in July 2008. Four trees ('Pera Rio' on rangpur lime rootstock [tree 1] and three trees of 'Folha Murcha' on rangpur lime rootstock [trees 2, 3, and 4]) were individually screened. At the Iguatemi Experimental Farm, four trees of sweet orange were screened in September 2010 ('1342' [tree 5], 'Ovale' MUT Proc. 43 5/96 [S] [tree 6], 'Valencia Campbell' [tree 7], and hybrid 'Murcott' on 'Orange Pear 96' rootstock [tree 8]). At the Chuva de Prata orchard, the Tahiti lime trees were grafted on Limão Cravo rootstock and the three trees were protected against reinfection using aphid screening in September 2010 (trees 9, 10, and 11).

Collection of leaf material for ' $\mathrm{Ca}$. L. asiaticus' monitoring and HLB severity assessment. Each of the selected trees in the field was divided into four sectors or quadrants by two perpendicular lines (as viewed from above), in which we assessed the distribution of HLB symptoms. In each quadrant, 10 leaves were collected once a month, giving preference to symptomatic leaves. Sampling of the Tahiti lime trees at the Chuva de Prata orchard and the sweet orange trees at the IEF experimental orchard was continued for 20 months, from October 2010 to May 2012. The sweet orange trees at the Estrela Farm orchard in Paranavaí were sampled over a period of 26 months, from April 2010 to May 2012. The leaf material that was collected was placed in paper bags and taken immediately to the laboratory for total DNA extraction. 
The severity of HLB symptoms in each quadrant of each tree was assessed using a scale where $-=$ no symptoms, $+=$ localized symptoms, $++=$ severe symptoms, and $+++=$ severe symptoms, with intense yellowing of leaves (the scale was converted to a 0 -to-3 ordinal scale for subsequent analysis). Severity of HLB symptoms at the Chuva de Prata orchard was assessed on 22 July 2010, 20 May 2011, and 10 May 2012; at the IEF orchard on 8 July 2010, 20 May 2011, and 10 May 2012; and at the Estrela Farm orchard on 7 June 2010, 12 May 2011, and 7 May 2012. Disease severity rating was performed by individuals familiar with both HLB symptoms and with the progression of the disease.

Purification and DNA quantification. The leaf blade was removed from the midrib and disposed of with each leaf using a sterile scalpel. The combined midribs (11) from each quadrant of the tree canopy were macerated in separate groups in sterile porcelain crucibles with the aid of liquid nitrogen to obtain a fine powder. Total DNA was extracted using the CTAB method (34). The concentration and quality of the DNA was evaluated using a spectrophotometer (Nanodrop 2000; Thermo Fisher Scientific Inc., Waltham, MA). All DNA samples were standardized to a concentration of approximately $100 \mathrm{ng} / \mu 1$ and stored at $-20^{\circ} \mathrm{C}$ until needed.

qPCR. The qPCR was conducted using a 7500 Fast Real Time PCR System (Applied Biosystems, Foster City, CA). The primer sequences (AS84F, 5'-TCACCGGCAGTCCCTATAAAAGT-3' and As180R, 5'-GGGTTAAGTCCCGCAACGA-3') and probe (As-NEDMGB-111T, 5'-ACATCTAGGTAAAAACC-3') were described previously by Coletta-Filho et al. (8).

The qPCR reactions were prepared to a final volume of $20 \mu \mathrm{l}$ using $2 \times$ TaqMan Fast Universal Master Mix (Applied Biosystems), the two primers $(0.8 \mu \mathrm{M})$, the probe for ' $\mathrm{Ca}$. Liberibacter asiaticus' $(0.2 \mu \mathrm{M}), 4 \mu \mathrm{l}$ of the standard DNA (Eukaryotic 18S rRNA at $100 \mathrm{ng} / \mu \mathrm{l}^{-1}$; Applied Biosystems) as an internal control to normalize the amount of total DNA in each reaction, and $1 \mu$ l of sterile Milli-Q water. Each qPCR cycle included two replicates of each sample DNA, two replicates of water as a negative control, and a positive control (samples of the HLB-infected trees kept in the greenhouse) of HLB. The amplification conditions were $50^{\circ} \mathrm{C}$ for $2 \mathrm{~min}, 95^{\circ} \mathrm{C}$ for $10 \mathrm{~min}$, and 40 cycles of $95^{\circ} \mathrm{C}$ for $15 \mathrm{~s}$ and $60^{\circ} \mathrm{C}$ for $1 \mathrm{~min}(8)$. The results were analyzed using ABI Prism software (version 1.4).

The threshold cycle $\left(C_{t}\right)$ values $\left(C_{t}\right.$ value refers to the number of PCR cycles required for the fluorescence signal to reach the threshold of detection) are inversely proportional to the amount of target nucleic acid in the sample (the lower the $C_{t}$ level, the greater the amount of target nucleic acid in the sample).

Statistical analysis. SAS (V9.3; SAS Institute, Cary, NC) was used for all analyses. The different $C_{t}$ values obtained in different seasons from October 2010 to May 2012 in all three orchards were analyzed using a repeated-measures mixed model with three factors, where season (spring, summer, autumn, and winter), orchard (two of sweet orange and one of Tahiti lime), and the interaction (season-orchard) were treated as fixed effects and tree was considered a repeated measure: $Y_{\mathrm{ijk}}=\mu+\alpha_{\mathrm{i}}+\beta_{\mathrm{j}}+\gamma_{\mathrm{k}}+\alpha \beta_{\mathrm{ij}}+\varepsilon_{\mathrm{ijk}}$, where $Y_{\mathrm{ijk}}$ is the predicted $\mathrm{C}_{\mathrm{t}}$ value, $\mu$ is the overall mean, $\alpha_{\mathrm{i}}$ is the fixed effect of season, $\beta_{\mathrm{j}}$ is the fixed effect of orchard, $\gamma_{\mathrm{k}}$ is the repeated measures effect of tree, $\alpha \beta_{\mathrm{ij}}$ is the interaction of season-orchard, and $\varepsilon_{\mathrm{ijk}}$ is the residual error. Where significant differences were observed among the different levels of the fixed effect (season), multiple comparisons among the levels were performed with Tukey's honestly significant difference (HSD) test $(\alpha=0.05)$. Diagnostic plots of the data (residuals, quantiles, and so on) showed the data to be normally distributed and amenable to analysis without the need for transformation.

A Spearman's rank correlation was used to investigate the association between symptom severity in each quadrat of the tree and corresponding $C_{t}$ value. Regression analysis was used to investigate the relationship between cumulative mean $C_{t}$ value and time since first sample to explore the long-term trends in $C_{t}$ value.

\section{Results}

The mean monthly temperature at the locations of each of the three orchards was similar during the sampling periods (Fig. 1). The mean temperatures were highest during the summer months (24.3 to $26.2^{\circ} \mathrm{C}$ ) and generally lowest in the winter and autumn months $\left(17.2\right.$ to $\left.24.5^{\circ} \mathrm{C}\right)$.

There was a main effect of season $(F=8.77, P$ value 0.0004$)$ but there were no significant effects of orchard or the interaction of seasonorchard (Table 1). The results of a Tukey's HSD means separation showed the effect of season on $C_{t}$ value (Table 2). On average, $C_{t}$ values were lowest in autumn and winter, suggesting that the titer of the bacterium was highest when mean temperatures were declining or coolest (mean across all locations 21.7 and $19.0^{\circ} \mathrm{C}$, respectively). However, although numerically lower, the $C_{t}$ value in winter was not different from that in spring or summer, when mean temperatures were 22.6 and $25.0^{\circ} \mathrm{C}$, respectively. Furthermore, in trees of each orchard throughout the sampling periods, mean $C_{t}$ value in relation to temperature (and season) tended to be lowest during the autumn and winter periods compared with the preceding spring and summer periods (Fig. 2A-C), although there was a tendency for an overall decline in mean $C_{t}$ value over the duration of the sampling period. The early and rapid increase in ' $\mathrm{Ca}$. L. asiaticus' titer in these trees in all three orchards is demonstrated by the decline in cumulative mean $\mathrm{C}_{\mathrm{t}}$ value with sample date (Fig. $3 \mathrm{~A}-\mathrm{C}$ ), which showed a consistent trend to stabilize with time, which was described by a logarithmic relationship (coefficient of determination $\left[R^{2}\right]=0.88$ to $0.95)$. Thus, the cumulative average ' $\mathrm{Ca}$. L. asiaticus' titer stabilized (although it may still cycle with season, the overall rate of decline slows with time).

The development of symptoms or a decline in $\mathrm{C}_{\mathrm{t}}$ value was evident during the course of the study (Table 3 ). The symptoms initially observed in the trees in the field were not always present in every

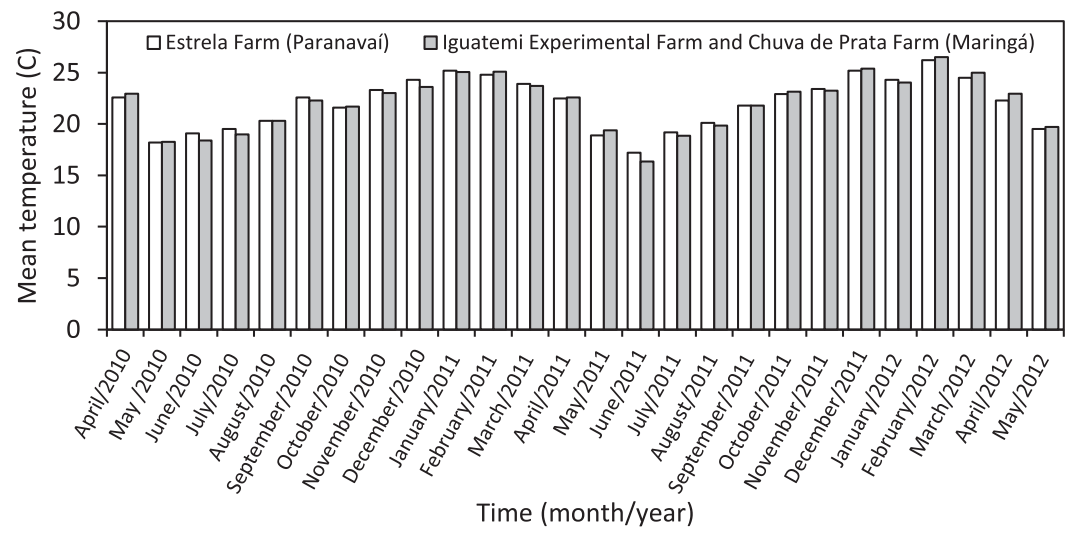

Fig. 1. Mean monthly temperatures for the locations of the three orchards where huanglongbing severity was assessed and mean cycle threshold values of 'Candidatus Liberibacter asiaticus' was measured in trees of sweet orange and Tahiti lime: Estrela Farm (Paranavai-PR) from April 2010 to May 2012; Iguatemi Experimental Farm, Universidade Estadual de Maringá, (Maringá-PR); and Chuva de Prata (Maringá-PR) from October 2010 to May 2012. 
quadrant but detection of ' $\mathrm{Ca}$. L. asiaticus' was most often possible even in quadrants that had poorly developed or no symptoms. Considering all quadrants sampled, the mean $\mathrm{C}_{\mathrm{t}}$ value declined in $85.7 \%$ of quadrat samples between 2010 and 2011 and declined in $92.9 \%$ of quadrat samples between 2010 and 2012. Overall, there was variation in individual tree symptom development and $\mathrm{C}_{\mathrm{t}}$ value over the duration of the experiment. For example, at the Estrela Farm orchard (sweet orange), ' $\mathrm{Ca}$. L. asiaticus' was detected in certain quadrants of the tree canopies at different times after sampling began. Tree 2, quadrant I, exhibited the most severe symptoms and, with the exception of the September 2010 sample, had $C_{t}$ values $<26.0$. However, tree 3, quadrants II and III, were asymptomatic, yet quadrant II had low $\mathrm{C}_{\mathrm{t}}$ values ranging from 22.0 to 24.0. In quadrant III, ' $\mathrm{Ca}$. L. asiaticus' was detected in the seventh month, and $C_{t}$ values ranged from 23.0 to 24.0 thereafter. With tree 4 , symptoms predominated at the top of the canopy, making it difficult to collect symptomatic material, and ' $\mathrm{Ca}$. L. asiaticus' was detected in quadrant I in the tenth month after sample collection started yet, in quadrant III, was found in the sixth month and thereafter. Even among HLB-asymptomatic samples, the $\mathrm{C}_{\mathrm{t}}$ values ranged from 18.0 to 37.5.

' $C a$. L. asiaticus' titer (based on $\mathrm{C}_{\mathrm{t}}$ values) sometimes had an irregular pattern with time even within the same quadrant, indicating that bacterial populations shifted from very low titers in one month whereas, in the following month or a few months later, the titers of bacteria were substantially higher (occasionally the reverse was also observed). For example, in quadrant 1 of tree 1 in January 2011, the $C_{t}$ value was 31.0 but, by February 2011, the $C_{t}$ value was 18.8 .

With increased population of the pathogen in the host, the onset and severity of symptoms was almost invariably observed. Sweet orange tree 5 (IEF orchard) initially had typical symptoms of HLB throughout the canopy of the tree, indicating rapid and comprehensive dispersion of the pathogen in the canopy, which was followed by decline of the host. In the first months of sample collection, the $C_{t}$ values were 34.0 to 37.0 but, with the progress of the disease, the $C_{t}$ values decreased and stabilized between 21.0 and 25.0.

In trees 9 (Tahiti lime at the Chuva de Prata orchard), quadrat I and IV were asymptomatic to mildly symptomatic, with somewhat variable $\mathrm{C}_{\mathrm{t}}$ values indicative of ' $\mathrm{Ca}$. L. asiaticus'. However, quadrants II and III had moderate symptoms of HLB yet also had variable $\mathrm{C}_{t}$ values indicative of ' $\mathrm{Ca}$. L. asiaticus'. With the development of foliar symptoms resulting in a blotchy-mottle in the entire canopy of

Table 1. Type III fixed effects for the repeated measures mixed model analysis for the effects of orchard, season, and the interaction on cycle threshold value of citrus trees of sweet orange and Tahiti lime infected with 'Candidatus Liberibacter asiaticus' in Brazil from October 2010 to May 2012y

\begin{tabular}{lcccl}
\hline Effect & Num DF & Den DF & $\boldsymbol{F}$ value & $\boldsymbol{P r}>\boldsymbol{F}$ \\
\hline Orchard & 2 & 8 & 3.10 & 0.1 \\
Season $^{\mathrm{z}}$ & 3 & 24 & 8.77 & 0.0004 \\
Orchard $\times$ season & 6 & 24 & 1.56 & 0.2
\end{tabular}

y Covariance parameter estimate for repeated measure of tree $=2.68$ (standard error $=1.31), Z$ value $=2.04(\operatorname{Pr}>Z=0.04)$. Model fit, Akaike Information Criterion $(\mathrm{AIC})=1,122.6$, AIC $($ corrected for sample size $)=1,124.6$, and Bayesian Information Criterion $=1,128.2$.

${ }^{\mathrm{z}}$ Seasons comprised the following months: spring (September to November), summer (December to February), autumn (March to May), and winter (June to August). quadrant III in tree 10, the fruit exhibited typical HLB-related deformation although, in other quadrants of the tree where the symptoms were less severe, the fruit had no HLB-related symptoms. Differences in $\mathrm{C}_{\mathrm{t}}$ values among quadrats of individual trees, seasonal shifts, and sudden changes may be due to the movement of the ' $\mathrm{Ca}$. L. asiaticus' bacteria from the roots, where ' $\mathrm{Ca}$. L. asiaticus' maintains a more consistent and uniformly distributed population (23). Growth flushes with concomitant nutrient demand from the roots can result in movement of the bacterium to the foliage.

Symptom severity remained constant only for tree 3 but increased from 2010 to 2012 for all other trees (Fig. 4A). Spearman's rank correlation confirmed an association between $C_{t}$ value and symptom severity (Fig. 4B) and, at lower $\mathrm{C}_{\mathrm{t}}$ values, when ' $\mathrm{Ca}$. L. asiaticus' titer was highest, the symptoms of HLB were also more severe.

\section{Discussion}

In citrus orchards in Paraná State in Brazil, the lowest $\mathrm{C}_{\mathrm{t}}$ values (which correspond to the highest ' $\mathrm{Ca}$. L. asiaticus' titer; 30) in foliage were obtained in the autumn months, indicating that this is the probably the most appropriate time for detection of the causal agent of HLB, ' $\mathrm{Ca}$. Liberibacter asiaticus', in citrus foliage in this region. It has been established that temperature can influence the $C_{t}$ values of HLB-diseased trees in the field (32) and this, in turn, can affect the survival of the pathogen in inoculated tissue (31). In this study, the $C_{t}$ values observed in spring and summer were statistically similar to those found in winter, while those found in autumn were significantly lower (but not different from those found in winter). Trees were maintained under screen throughout the experiment to prevent reinfection influencing titer; therefore, fluctuations were probably due to the natural in planta ' $\mathrm{Ca}$. L. asiaticus' population due to inoculum movement from roots (23) or the direct effects of temperature on the bacteria. Although roots may contain the consistently highest and most uniform ' $\mathrm{Ca}$. L. asiaticus' populations, it is currently impractical to sample roots on a large scale (23), as would be required for purposes of survey or field experiment; therefore, foliage remains an important sample type to identify infection with ' $\mathrm{Ca}$. L. asiaticus'. It is likely that the temperature under the screen used to protect the trees from reinfection was slightly different from the ambient but any temperature differences due to the screens would be unlikely to be of such magnitude as to influence the ' $\mathrm{Ca}$. L. asiaticus' population in the foliage (temperature under the screen was not measured in this study). Thus, the lower temperatures prevalent in autumn and winter appear to cause a reduction of the $C_{t}$ value in the foliage of citrus (32), and this might influence transmission rates of ' $\mathrm{Ca}$. L. asiaticus' from foliage due to psyllid acquisition (31). Other studies, two from Florida $(21,42)$ and one from Pakistan (37), reported similar results that indicated that material collected in the late summerautumn-early winter period had the greatest probability of testing positive for ' $\mathrm{C} a$. L. asiaticus', and had the highest ' $\mathrm{Ca}$. L. asiaticus' bacterial titers. Thus, the data from our study confirms these previous observations of the seasonal dynamics of $\mathrm{C}_{\mathrm{t}}$ values for ' $\mathrm{Ca}$. $\mathrm{L}$. asiaticus' in the foliage of citrus under comparable climatic conditions.

The lowest temperatures were recorded in the months corresponding to autumn (approximately $20^{\circ} \mathrm{C}$ ). The highest temperatures were recorded in the summer months (approximately $25^{\circ} \mathrm{C}$ ). The greater efficiency for infection of citrus with ' $\mathrm{Ca}$. L. asiaticus' is 22 to $27^{\circ} \mathrm{C}(13)$, which is thought to play an important role in

Table 2. Mean cycle threshold $\left(\mathrm{C}_{\mathrm{t}}\right)$ values of 'Candidatus Liberibacter asiaticus' in trees of sweet orange and Tahiti lime and mean seasonal temperatures in northwestern Paraná State, Brazil, from October 2010 to May 2012

\begin{tabular}{llcc}
\hline Season & \multicolumn{1}{c}{ Months } & $\begin{array}{c}\text { Least square mean } \mathbf{C}_{\mathbf{t}} \text { values } \\
\text { (standard error) }\end{array}$ & $\begin{array}{c}\text { Mean temperature }\left({ }^{\mathbf{2}} \mathbf{C}\right) \\
(\text { standard deviation) }\end{array}$ \\
\hline Spring & September-November & $26.8(0.63) \mathrm{A}$ & $22.6(0.7)$ \\
Summer & December-February & $26.5(0.61) \mathrm{A}$ & $25.0(0.8)$ \\
Autumn & March-May & $24.4(0.61) \mathrm{B}$ & $21.7(2.3)$ \\
Winter & June-August & $25.5(0.70) \mathrm{AB}$ & $19.0(1.2)$ \\
\hline
\end{tabular}

${ }^{\mathrm{z}}$ Numbers with different letters are significantly different based on linear mixed model analysis and Tukey's means separation $(\alpha=0.05)$. 
the epidemiology of the disease, supporting survival and availability of inoculum in the field (3) and in the vector (37). Thus, temperature can be related to changes in bacterial titers, affecting the population of the pathogen and its reproduction (32), which may also

A

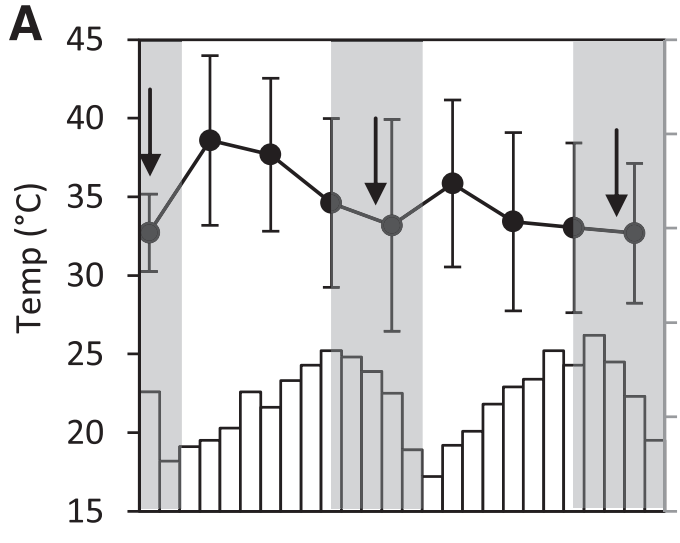

B

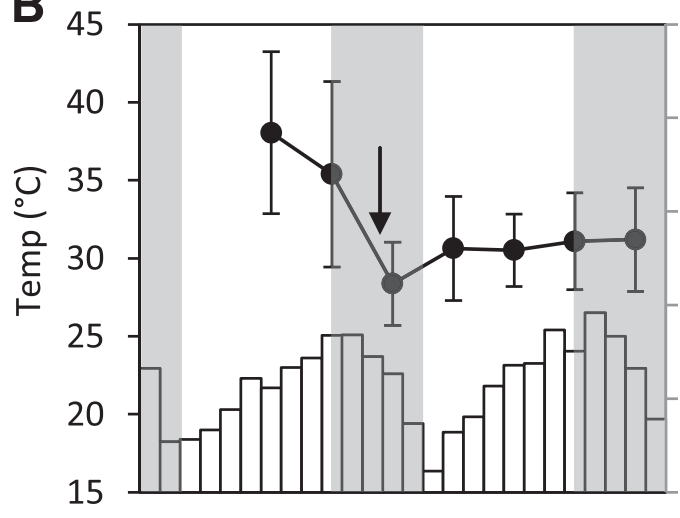

C

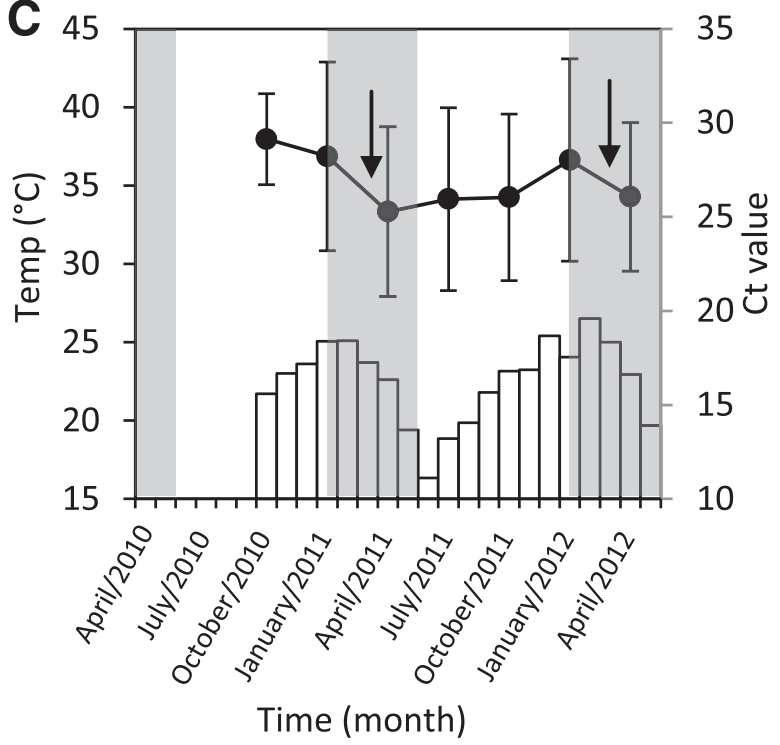

Fig. 2. Mean seasonal cycle threshold $\left(C_{t}\right)$ values (titer of 'Candidatus Liberibacter asiaticus') and temperature in relation to time on $\mathbf{A}$, sweet orange at the Estrela Farm (Paranavai); B, sweet orange at the Iguatemi Experimental Farm, Universidade Estadual de Maringá; and C, Tahiti lime at the Chuva de Prata orchard (Maringá) in Parana State, Brazil. Note that most lower $C_{t}$ values coincide with the late summer-autumn months (shaded areas and arrows). Conversely, highest $C_{t}$ values (lowest titer) tended to be in spring and early summer. The seasons comprised mean $\mathrm{C}_{\mathrm{t}}$-values of the following months: spring (September to November), summer (December to February), autumn, (March to May), and winter (June to August). Sample standard deviations shown are for all samples collected in each season. be due, in part, to the influence of seasonal conditions on transport of the pathogen with carbohydrate to and from the roots (23). The low incidence and slow spread of ' $\mathrm{Ca}$. L. asiaticus' by $\mathrm{D}$. citri in production fields in warmer regions of São Paulo State might
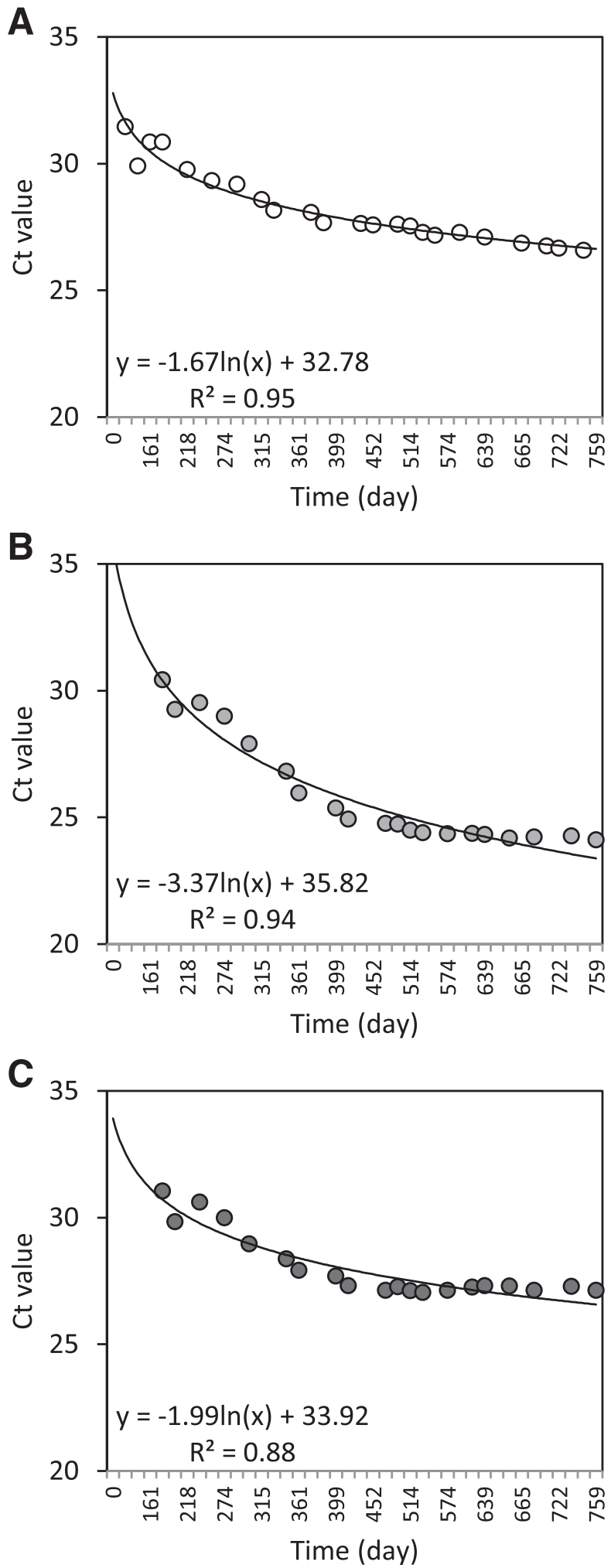

Fig. 3. Relationship between the cumulative mean cycle threshold $\left(C_{t}\right)$ value and time over the specified sampling period (days since first positive detection in trees in orchards of A, sweet orange at the Estrela Farm (Paranavaí); B, sweet orange at the Iguatemi Experimental Farm, Universidade Estadual de Maringá; and C, Tahiti lime at the Chuva de Prata orchard (Maringá) in Parana State, Brazil. As indicated, a logarithmic regression solution described the relationship, showing the initial decline in $C_{t}$ values with time in the first several months after initial detection of huanglongbing in the trees. 
Table 3. Distribution of symptoms of huanglongbing (HLB) caused by 'Candidatus Liberibacter asiaticus' in canopies of citrus trees (sweet orange [Citrus sinensis] and Tahiti lime [C. aurantifolia]) and mean cycle threshold $\left(\mathrm{C}_{\mathrm{t}}\right)$ values monitored over the sampling period from 2010 to 2012

\begin{tabular}{|c|c|c|c|c|c|c|c|c|c|}
\hline \multirow[b]{2}{*}{ Orchard } & \multirow[b]{2}{*}{ Tree } & \multirow[b]{2}{*}{ Cultivar } & \multirow{2}{*}{$\begin{array}{c}\text { Canopy } \\
\text { quadrant }\end{array}$} & \multicolumn{3}{|c|}{$\begin{array}{l}\text { HLB symptom } \\
\text { severity }\end{array}$} & \multicolumn{3}{|c|}{$\begin{array}{c}\text { 'Ca. L. asiaticus' mean annual } \mathrm{C}_{\mathrm{t}} \text { value } \\
\text { (standard deviation) }\end{array}$} \\
\hline & & & & 2010 & 2011 & $\overline{2012}$ & 2010 & 2011 & 2012 \\
\hline \multirow[t]{16}{*}{ Estrela Farm (sweet orange) } & \multirow[t]{4}{*}{1} & \multirow[t]{4}{*}{ Pêra-Rio } & I & - & + & + & $28.15(4.69)$ & $23.52(4.48)$ & $24.26(2.17)$ \\
\hline & & & II & - & + & + & $26.59(4.88)$ & $22.20(2.37)$ & $22.80(1.65)$ \\
\hline & & & III & + & + & + & $21.10(1.96)$ & $23.85(2.94)$ & $22.94(1.21)$ \\
\hline & & & IV & - & + & + & $27.98(3.28)$ & $23.97(4.12)$ & $23.20(2.72)$ \\
\hline & \multirow[t]{4}{*}{2} & \multirow[t]{4}{*}{ Folha Murcha } & I & ++ & +++ & +++ & $24.61(3.84)$ & $25.15(3.50)$ & $22.63(1.24)$ \\
\hline & & & II & - & + & + & $\ldots$ & $29.73(6.86)$ & $29.86(7.08)$ \\
\hline & & & III & - & + & + & $\cdots$ & $29.61(5.50)$ & $25.51(1.93)$ \\
\hline & & & IV & + & + & + & $30.12(3.17)$ & $27.33(5.37)$ & $22.19(0.98)$ \\
\hline & \multirow[t]{4}{*}{3} & \multirow[t]{4}{*}{ Folha Murcha } & I & + & + & + & $27.08(0.96)$ & $22.59(2.21)$ & $22.14(0.70)$ \\
\hline & & & II & - & - & - & $26.03(3.72)$ & $23.82(3.04)$ & $23.87(1.83)$ \\
\hline & & & III & - & - & - & $35.60(*)$ & $28.68(5.83)$ & $24.20(1.41)$ \\
\hline & & & IV & + & + & + & $28.24(4.62)$ & $25.45(3.79)$ & $23.66(2.57)$ \\
\hline & \multirow[t]{4}{*}{4} & \multirow[t]{4}{*}{ Folha Murcha } & I & - & + & + & $38.72(1.82)$ & $31.92(4.99)$ & $26.84(3.76)$ \\
\hline & & & II & + & + & + & $27.86(4.68)$ & $28.32(4.08)$ & $22.17(3.40)$ \\
\hline & & & III & + & + & + & $34.56(*)$ & $29.12(4.67)$ & $22.59(1.02)$ \\
\hline & & & IV & - & + & + & $28.81(4.85)$ & $28.40(4.84)$ & $27.46(6.85)$ \\
\hline \multirow{16}{*}{$\begin{array}{l}\text { Iguatemi Experimental Farm, } \\
\text { UEM (sweet orange) }\end{array}$} & \multirow[t]{4}{*}{5} & \multirow[t]{4}{*}{1342} & I & ++ & +++ & +++ & $27.01(4.35)$ & $24.56(3.89)$ & $23.70(1.77)$ \\
\hline & & & II & ++ & +++ & +++ & $30.13(1.95)$ & $25.75(3.74)$ & 24.49 (1.38) \\
\hline & & & III & ++ & +++ & +++ & $32.17(5.77)$ & $26.71(3.33)$ & $24.53(1.85)$ \\
\hline & & & IV & ++ & +++ & +++ & $31.53(5.52)$ & $23.31(2.37)$ & 24.99 (1.99) \\
\hline & \multirow[t]{4}{*}{6} & \multirow{4}{*}{$\begin{array}{l}\text { Ovale Mut Proc. } \\
435 / 96 \text { (S) }\end{array}$} & I & - & + & + & $29.04(3.48)$ & $22.72(2.18)$ & $24.78(2.64)$ \\
\hline & & & II & - & ++ & ++ & $27.96(0.55)$ & $22.66(3.30)$ & $23.80(2.43)$ \\
\hline & & & III & + & ++ & ++ & $30.52(3.59)$ & $22.78(1.70)$ & $22.97(3.73)$ \\
\hline & & & IV & + & ++ & ++ & $28.18(5.51)$ & $23.55(2.77)$ & $22.59(3.33)$ \\
\hline & \multirow[t]{4}{*}{7} & Valencia Campbell & I & + & ++ & ++ & $27.33(3.23)$ & $21.88(2.00)$ & $22.52(3.07)$ \\
\hline & & & II & + & ++ & ++ & $24.86(0.76)$ & $21.25(1.70)$ & $23.16(3.88)$ \\
\hline & & & III & - & ++ & ++ & $34.17(6.33)$ & $21.42(1.88)$ & $22.10(2.45)$ \\
\hline & & & IV & - & ++ & ++ & $28.07(4.29)$ & $21.92(2.17)$ & $21.17(1.34)$ \\
\hline & 8 & Tangor Murcott & I & - & + & + & $33.14(8.13)$ & $25.25(4.71)$ & $22.46(1.92)$ \\
\hline & & & II & + & ++ & ++ & $27.33(2.58)$ & $22.13(2.30)$ & $22.06(2.32)$ \\
\hline & & & III & + & ++ & ++ & $29.14(4.32)$ & $21.23(2.42)$ & $23.96(3.99)$ \\
\hline & & & IV & - & + & + & $32.45(5.00)$ & $21.90(1.91)$ & $21.32(1.16)$ \\
\hline Chuva de Prata (Tahiti lime) & 9 & C. aurantifolia & I & - & - & + & $31.50(*)$ & $32.52(3.94)$ & $34.59(2.98)$ \\
\hline & & & II & + & ++ & ++ & $30.71(*)$ & $24.99(2.53)$ & $26.45(2.89)$ \\
\hline & & & III & + & ++ & ++ & $28.68(*)$ & $33.31(4.44)$ & $31.61(4.32)$ \\
\hline & & & IV & - & - & + & $34.66(*)$ & $36.41(0.92)$ & $30.36(9.95)$ \\
\hline & 10 & C. aurantifolia & I & - & ++ & +++ & $27.65(*)$ & $23.96(2.36)$ & $26.70(2.91)$ \\
\hline & & & II & + & ++ & +++ & $30.70(2.32)$ & $23.59(2.72)$ & $26.35(2.85)$ \\
\hline & & & III & ++ & +++ & +++ & $32.68(5.59)$ & $24.63(2.20)$ & $25.18(5.78)$ \\
\hline & & & IV & ++ & +++ & +++ & $26.95(1.54)$ & $24.14(3.09)$ & $24.78(1.61)$ \\
\hline & 11 & C. aurantifolia & I & + & ++ & ++ & $31.71(3.64)$ & $23.82(1.84)$ & 24.09 (1.84) \\
\hline & & & II & - & + & + & $31.07(6.78)$ & $24.23(2.47)$ & $25.70(2.05)$ \\
\hline & & & III & - & + & + & $28.38(1.93)$ & $24.51(2.28)$ & $24.63(2.44)$ \\
\hline & & & IV & + & ++ & ++ & $29.84(2.99)$ & $26.27(4.31)$ & $24.26(3.39)$ \\
\hline
\end{tabular}

\footnotetext{
y Symbols: $-=$ no symptoms, $+=$ localized symptoms, $++=$ severe symptoms, and $+++=$ severe symptoms with intense yellowing of leaves.
}

$\mathrm{z}$ An asterisk (*) indicates insufficient data to calculate a standard deviation (standard deviations are based on all $\mathrm{C}_{\mathrm{t}}$ values measured in that year).

also be due to a direct influence of the ambient temperature on the titers of ' $\mathrm{Ca}$. L. asiaticus' in leaves and possibly in the vector $(21,33,37,42)$.

The months of March, April, and May correspond to autumn in Brazil, which coincides not only with a period of declining temperatures and precipitation but also with the phase of citrus floral induction. The citrus trees go into a dormant phase of little or no vegetative growth (36), during which there is an accumulation of reserves that are rapidly utilized in the development of reproductive structures (28). The period of floral induction occurs in those months, when the in tree population of ' $\mathrm{Ca}$. L. asiaticus' has the highest titers (and when nutrient reserves are mobilized), suggesting that the phenology of citrus, perhaps in addition to the effects of temperature, might have an influence on bacterial titers. The increase in ' $\mathrm{Ca}$. L. asiaticus' titer might be due to the transport of the pathogen with mobilized carbohydrate reserves from the roots $(23)$.
The mean $\mathrm{C}_{\mathrm{t}}$ values measured in both sweet orange and Tahiti lime trees decreased with sample date (i.e., ' $\mathrm{Ca}$. L. asiaticus' titer increased). Consequently, we observed the development of symptoms of HLB, which became increasingly severe. The severity of foliar symptoms of HLB increasing with time has been reported previously with inoculated trees (30). Thus, the expression of symptoms of HLB is directly related to the titer of the pathogen, and a low $C_{t}$ value (high bacterial population) can result in the emergence of symptoms $(8,41)$. Although ' $\mathrm{Ca}$. L. asiaticus' may reproduce slowly in some parts of the tree, it appears to have the ability to be transferred from the roots relatively rapidly; for example, to rapidly growing shoots or zones of floral initiation which are powerful nutrient sinks $(23,41)$. This may explain why detection of ' $\mathrm{Ca}$. L. asiaticus' took up to 6 months in some quadrants of these trees, and yet was detected immediately, or suddenly, in other quadrants, over the duration of the sampling in the field. The importance of the population of ' $\mathrm{Ca}$. L. asiaticus' in the roots (23), and the more consistent titer found in roots is a recent 
development that might have ramifications for future detection and sampling of the pathogen. Nonetheless, the importance of the canopy inoculum for acquisition of ' $\mathrm{Ca}$. L. asiaticus' by the psyllid and subsequent transmission in orchards remains a vital component to understanding disease spread in the field.

In all three locations and in both species (sweet orange and Tahiti lime), asymmetric and deformed fruit were observed. Canopy quadrants with a few mild foliar symptoms exhibited mostly asymptomatic fruit; however, with the development of more severe foliar symptoms, the production of deformed fruit was more widespread. The observation that symptomatic fruit are produced within or close to HLB-symptomatic areas of the canopy with generally high titers of bacteria has been reported before (40). Most often, ' $C a$. L. asiaticus' in asymptomatic trees or asymptomatic leaves from otherwise symptomatic trees is found at low titers $(26,40,41)$, and high bacterial titer associated with mild expression of symptoms has been suggested to indicate better adaptation of the Asian species (' $\mathrm{Ca}$. L. asiaticus') compared with the American species (' $\mathrm{Ca}$. L. americanus') of the pathogen in Brazil (30).

The results of this study provide further understanding and confirmation of the population dynamics of ' $\mathrm{Ca}$. L. asiaticus' in foliage of citrus trees, the development of the disease, and its relationship with the host. The ambient temperature to which the tree is exposed in the field, the phenology of the host, and the time of sampling are factors that impact bacterial titers seasonally and also contribute to the irregular distribution in the host. This information can help to provide an understanding of the population dynamics of ' $\mathrm{Ca}$. L. asiaticus', which is valuable both for sampling in future research and for development of appropriate techniques for management of the disease (38).
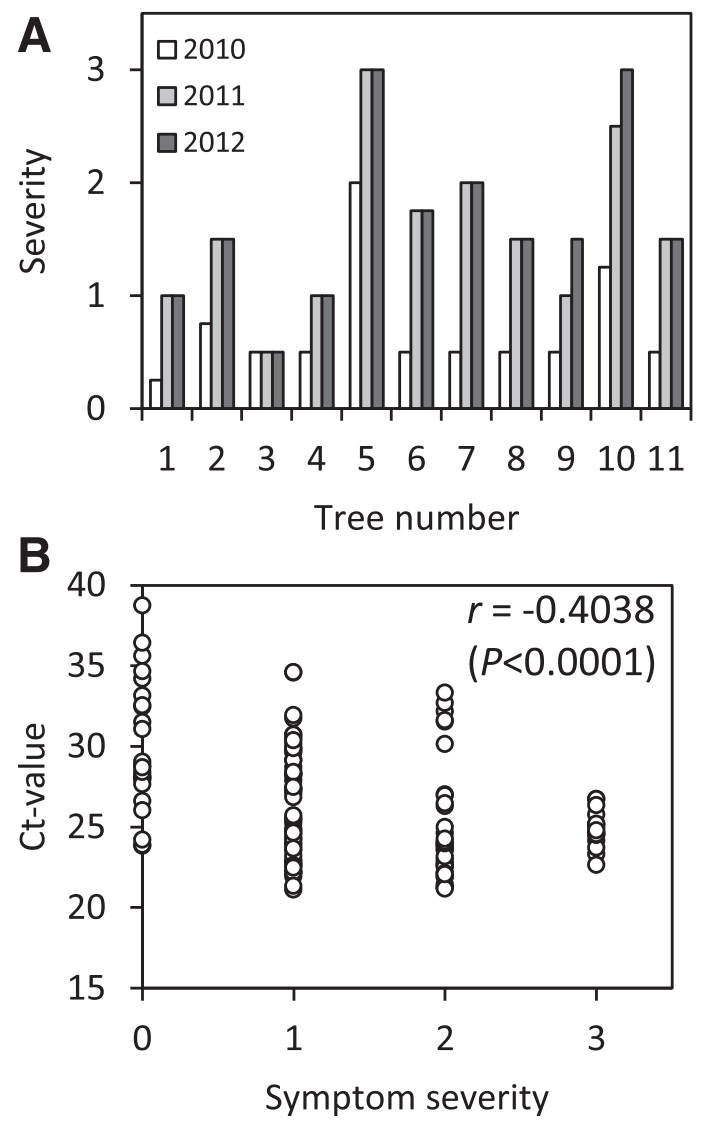

Fig. 4. A, Severity of symptoms of huanglongbing on 11 trees of citrus in each of three consecutive seasons (2010 to 2012) as estimated visually. B, Spearman's rank correlation analysis of the association between severity ratings in relation to cycle threshold $\left(C_{t}\right)$ values of 'Candidatus Liberibacter asiaticus' in each of four quadrants of the 11 citrus trees in Parana State, Brazil. The severity scale was as follows: $0=$ no symptoms, 1 = localized symptoms, 2 = severe symptoms, and 3 = severe symptoms, with intense yellowing of leaves.

\section{Acknowledgments}

We thank E. Bertolini, M. Cambra, and E. Vidal from the Plant Protection Centre of the Instituto Valenciano de Investigaciones Agrarias (IVIA), Valencia, Spain, for critical reading of the manuscript; and Coordenação de Aperfeiçoamento de Pessoal de Nível Superior (CAPES) for financial support. A. V. Sauer is the recipient of Ph.D. grants from CAPES, Ministério da Educação of Brazil. This work was supported by a grant-in-aid for scientific research from $\mathrm{CNPq}$ (578247/2008-9)

\section{Literature Cited}

1. Alvarez, A. M. 2004. Integrated approaches for detection of plant pathogenic bacteria and diagnosis of bacterial diseases. Annu. Rev. Phytopathol. 42:339-366.

2. Bach, H.-J., Tomanova, J., Schloter, M., and Munch, J. C. 2002. Enumeration of total bacteria and bacteria with genes for proteolytic activity in pure cultures and in environmental samples by quantitative PCR mediated amplification. J. Microbiol. Methods 49:235-245.

3. Bassanezi, R. B., Lopes, S. A., Belasque, J., Jr., Spósito, M. B., Yamamoto, P. T., Miranda, M. P., Teixeira, D. C., and Wulff, N. A. 2010. Epidemiologia do Huanglongbing e suas implicações para o manejo da doença. Citrus Res. Technol. 31:11-23.

4. Bové, J. M. 2006. Huanglongbing: A destructive, newly-emerging, centuryold disease of citrus. J. Plant Pathol. 88:7-37.

5. Brlansky, R. H., and Rogers, M. E. 2007. Citrus huanglongbing: Understanding the vector-pathogen interaction for disease management. Online publication. APSnet Features. 10.1094/APSnetFeature-2007-1207.

6. Cen, Y., Zhang, L., Xia, Y., Guo, J., Deng, X., Zhou, W., Sequeira, R., Gao, J., Wang, Z., Yue, J., and Gao, Y. 2012. Detection of 'Candidatus Liberibacter asiaticus' in Cacopsylla (Psylla) citrisuga (Hemiptera Psyllidae). Florida Entomol. 95:304-311.

7. Chung, K. R., and Brlansky, R. H. 2005. Citrus diseases exotic to Florida: Huanglongbing (citrus greening). Online publication. http://polkhort.ifas.ufl edu/documents/publications/Citrus\%20Greening.pdf

8. Coletta-Filho, H. D., Carlos, E. F., Alves, K. C. S., Pereira, M. A. R., Boscariol-Camargo, R. L., Souza, A. A., and Machado, M. A. 2010. In planta multiplication and graft transmission of 'Candidatus Liberibacter asiaticus' revealed by Real-Time PCR. Eur. J. Plant Pathol. 126:53-60.

9. Coletta-Filho, H. D., Carlos, E. F., Lotto, L. L., Luciane, F. C., Alves, K. C. S., Pereira, M. A. R., and Machado, M. A. 2010. Prevalence of 'Candidatus Liberibacter' spp. in HLB-diseased Citrus Plants in São Paulo State, Brazil. Pages 110-115 in: Proc. 17th Conf. Int. Organ. Citrus Virol., Cordeiropolis, São Paulo, Brazil.

10. Coletta-Filho, H. D., Targon, M. L. P. N., Takita, M. A., De Negri, J. D., Pompeu J., Jr., Machado, M. A., do Amaral, A. M., and Muller, G. W. 2004. First report of the causal agent of Huanglongbing ("Candidatus Liberibacter asiaticus") in Brazil. Plant Dis. 88:1382.

11. da Graça, J. V. 1991. Citrus greening disease. Annu. Rev. Phytopathol. 29:109-136.

12. Donovan, N. J., Beattie, G. A. C., Chambers, G. A., Holford, P., Englezou, A., Hardy, S., Dorjee, Wangdi, P., Thinlay, and Om, N. 2012. First report of 'Candidatus Liberibacter asiaticus' in Diaphorina communis. Australas. Plant Dis. Notes 7:1-4.

13. FAO-Food and Agriculture Organization of the United Nations. 2013. FAO Statistical Yearbook 2013-World Food and Agriculture. Online publication. <http://www.fao.org/docrep/018/i3107e/i3107e.PDF

14. Feichtenberger, E., Bassanezi, R. B., Spósito, M. B., and Belasque, J., Jr. 2005 Doenças dos citros. Pages 239-269 in: Manual de Fitopatologia: Doenças das Plantas Cultivadas. H. Kimati, L. Amorim, J. A. M. Rezende, A. Bergamin Filho, and L. E. A. Camargo, eds. Agronômica Ceres, São Paulo, Brazil.

15. Gottwald, T. R. 2010. Current epidemiological understanding of citrus huanglongbing. Annu. Rev. Phytopathol. 48:119-139.

16. Gottwald, T. R., Aubert, B., and Zhao, X.-Y. 1989. Preliminary analysis of citrus greening (Huanglongbing) epidemics in the People's Republic of China and French Reunion Island. Phytopathology 79:687-693.

17. Gottwald, T. R., da Graça, J. V., and Bassanezi, R. B. 2007. Citrus Huanglongbing: The pathogen and its impact. Online publication. Plant Health Prog. 10.1094/PHP-2007-0906-01-RV

18. Gravena, S. 1998. Manejo ecológico de pragas dos citros-aspectos práticos Laranja 19:61-78.

19. Hu, H., Davis, M. J., and Brlansky, R. H. 2013. Quantification of live 'Candidatus Liberibacter asiaticus' populations using real-time PCR and propidium monoazide. Plant Dis. 97:1158-1167.

20. Instituto Brasileiro de Geografia e Estatística-IBGE. 2012. Indicadores IBGE, Estatística da produção agrícola, julho de 2013. Online publication. http://www.ibge.gov.br/home/estatistica/indicadores/agropecuaria/lspa/ estProdAgr_201307.pdf

21. Irey, M. S., Gast, T., Cote, J., Gadea, P., Santiago, O., Briefman, L., and Graham, J. H. 2011. Seasonal variability in HLB testing data in plant and psyllid samples in Florida. Page 72 in: Proc. 2nd Int. Res. Conf. Huanglongbing, Orlando, FL. J. K. Burns, J. H. Graham, and T. R. Gottwald, eds. Online publication. http://www.plantmanagementnetwork.org/proceedings/irchlb/2011/ presentations/IRCHLB_2011_4.6.pdf

22. Jagoueix, S., Bové, J. M., and Garnier, M. 1996. PCR detection of the two 'Candidatus' liberibacter species associated with greening disease of citrus Mol. Cell. Probes 10:43-50. 
23. Johnson, E. G., Wu, J., Bright, D. B., and Graham, J. H. 2014. Association of 'Candidatus Liberibacter asiaticus' root infection, but not phloem plugging with root loss on huanglongbing-affected trees prior to appearance of foliar symptoms. Plant Pathol. 63:290-298.

24. Kawabe, K., Truc, N. T. N., Lan, B. T. N., Hong, L. T. T., and Onuki, M. 2006. Quantification of DNA of citrus huanglongbing pathogen in diseased leaves using competitive PCR. J. Gen. Plant Pathol. 72:355-359.

25. Li, W., Hartung, J. S., and Levy, L. 2006. Quantitative real-time PCR for detection and identification of Candidatus Liberibacter species associated with citrus huanglongbing. J. Microbiol. Methods 66:104-115.

26. Li, W., Hartung, J. S., and Levy, L. 2007. Evaluation of DNA amplification methods for improved detection of "Candidatus Liberibacter species" associated with citrus huanglongbing. Plant Dis. 91:51-58.

27. Li, W., Levy, L., and Hartung, J. S. 2009. Quantitative distribution of 'Candidatus Liberibacter asiaticus' in citrus plants with citrus huanglongbing. Phytopathology 99:139-144.

28. Lima, J. E. O. 1989. Florescimento e frutificação em citros. Laranja 2: 523-530.

29. Lin, H., Chen, C., Doddapaneni, H., Duan, Y., Civerolo, E. L., Bai, X., and Zhao, X. 2010. A new diagnostic system for ultra-sensitive and specific detection and quantification of 'Candidatus Liberibacter asiaticus', the bacterium associated with citrus Huanglongbing. J. Microbiol. Methods 81: $17-25$.

30. Lopes, S. A., Bertolini, E., Frare, G. F., Martins, E. C., Wulff, N. A., Teixeira, D. C., Fernandes, N. G., and Cambra, M. 2009. Graft transmission efficiencies and multiplication of 'Candidatus Liberibacter americanus' and ' $\mathrm{Ca}$. Liberibacter asiaticus' in citrus plants. Phytopathology 99:301-306.

31. Lopes, S. A., and Frare, G. F. 2008. Graft transmission and cultivar reaction of citrus to 'Candidatus Liberibacter americanus'. Plant Dis. 92:21-24.

32. Lopes, S. A., Frare, G. F., Bertolini, E., Cambra, M., Fernandes, N. G., Ayres, A. J., Marin, D. R., and Bové, J. M. 2009. Liberibacters associated with citrus huanglongbing in Brazil: 'Candidatus Liberibacter asiaticus' is heat tolerant, ' $C a$. L. americanus' is heat sensitive. Plant Dis. 93:257-262.

33. Lopes, S. A., Luiz, F. Q. B. Q., Martins, E. C., Fassini, C. G., Sousa, M. C., Barbosa, J. C., and Beattie, G. A. C. 2013. 'Candidatus Liberibacter asiaticus' titers in citrus and acquisition rates by Diaphorina citri are decreased by higher temperature. Plant Dis. 97:1563-1570.

34. Murray, M. G., and Thompson, W. F. 1980. Rapid isolation of high molecular weight plant DNA. Nucleic Acids Res. 239:487-491.
35. Nunes, W. M. C., Zanutto, C. A., Rinaldi, D. A. M. F. C., Croce Filho, J, Azevedo, M. L., Leite, R. P., Jr., Coletta-Filho, H. D., Vicentini, S., and Corazza-Nunes, M. J. 2007. Primeira constatação de Huanglongbing em pomar comercial de citros no Estado do Paraná. Fitopatol. Bras. (Suppl.) 32. 1094.

36. Rasmussen, G. K., Peynado, A., and Hilgeman, R. 1966. The organic acid content of Valencia oranges from four locations in the United States. Proc. Am. Soc. Hortic. Sci. 89:206-210.

37. Razi, M. F., Keremane, M. L., Ramadugu, C., Roose, M., Khan, I. A., and Lee, R. F. 2014. Detection of citrus huanglongbing-associated 'Candidatus Liberibacter asiaticus' in citrus and Diaphorina citri in Pakistan, seasonal variability, and implications for disease management. Phytopathology 104: 257-268.

38. Tatineni, S., Sagaram, U. S., Gowda, S., Robertson, C. J., Dawson, W. O. Iwanami, T., and Wang, N. 2008. In planta distribution of 'Candidatus Liberibacter asiaticus' as revealed by polymerase chain reaction (PCR) and real-time PCR. Phytopathology 98:592-599.

39. Teixeira, D. C., Danet, J. L., Eveillard, S., Martins, E. C., Jesus Junior, W. C. Yamamoto, P. T., Lopes, S. A., Bassanezi, R. B., Ayres, A. J., Saillard, C., and Bové, J. M. 2005. Citrus huanglongbing in São Paulo State, Brazil: PCR detection of the "Candidatus' Liberibacter species associated with the disease. Mol. Cell. Probes 19:173-179.

40. Teixeira, D. C., Saillard, C., Couture, C., Martins, E. C., Wulff, N. A. Eveillard-Jagoueix, S., Yamamoto, P. T., Ayres, A. J., and Bové, J. M. 2008. Distribution and quantification of Candidatus Liberibacter americanus, agent of huanglongbing disease of citrus in São Paulo State, Brasil, in leaves of an affected sweet orange tree as determined by PCR. Mol. Cell. Probes 22: 139-150.

41. Trivedi, P., Sagaram, U. S., Kim, J. -S., Brlansky, R. H., Rogers, M. E. Stelinski, L. L., Oswalt, C., and Wang, N. 2009. Quantification of viable Candidatus Liberibacter asiaticus in hosts using quantitative PCR with the aid of ethidium monoazide (EMA). Eur. J. Plant Pathol. 124 553-563.

42. Zhang, M., Powell, C. A., Guo, Y., Benyon, L., and Duan, Y. 2013. Characterization of the microbial community structure in Candidatus Liberibacter asiaticus-infected citrus plants treated with antibiotics in the field. BMC Microbiol. 13:112.

43. Zhao, X.-Y. 1981. Citrus yellow shoot (Huanglongbing) in China: A review. Proc. Int. Soc. Citricult. 1:466-469. 